he became Netherlands Consul-General in Calcutta and in 1938 Minister to Turkey. In 1945 he headed the Netherlands Legation in South Africa and in 1948 he was appointed to the important post of Ambassador to the U.S.S.R.

Dr. Visser received many honours including the Gold Medal of the Société de Géographie and the Back Grant of the Royal Geographical Society; he was also an honorary member of many mountaineering clubs. He was the author of many works, some of general or political interest, but mostly on glaciers and mountaineering.

Between I92I and 1935 he led four expeditions to the Karakoram and his account of that part of the world, written in conjunction with his first wife (Wissenschaftliche Ergebnisse der Niederländischen Expeditionen in den Karakorum und die angrenzenden Gebiete in den fahren I922, I925, 1929-30 und 1935, Bd. 2, Glaziologie : Leiden, E. J. Brill) ranks as one of the earlier classics of the modern glaciology.

\title{
CARLO SOMIGLIANA
}

Carlo Somigliana, Professor Emeritus of the University of Turin, died on 20 June 1955 in his ninety-sixth year. Somigliana was internationally renowned as a mathematician and physicist and his contributions to theoretical glaciology were of considerable importance and interest.

He developed a theory of glacier flow with the aim of finding a relationship and therefore a formula which would serve to determine the thickness of a glacier by means of its surface movement. The retreat of the Rodano Glacier, on which observations of surface speed had previously been carried out by Swiss glaciologists, enabled Somigliana to calculate the value of the effective coefficient of viscosity of the glacier ice by means of the formulae of his theory and his knowledge of the profile of the valley bottom. The coefficient appears in the formulae themselves. Somigliana's formula has been widely applied, even recently, to determine the thickness of many glaciers. Direct evidence obtained by other methods has confirmed its practical value.

Somigliana was the founder and President of the Comitato Glaciologico Italiano and for many years was its leading spirit. Much of his glaciological work was published in the Bulletin of that Society during the 1930's but his famous "Sulla profondità dei ghiacciai" appeared in Rendiconti della R. Accademia Nazionale dei Lincei as early as $192 \mathrm{r}$.

\section{GLACIOLOGICAL OBSERVATIONS ON SOME OF THE OUTLET GLACIERS OF SOUTH-WEST VATNAJÖKULL, ICELAND, I 954}

\author{
By Cuchlaine A. M. King and J. D. Ives \\ (University of Nottingham)
}

(Continued from Vol. 2, No. 18, 1955, p. 563-69)

\section{Part II: OGIVES} \begin{abstract}
Observations and measurements of ogives on Morsárjökull, Svinafellsjökull and Falljökull are given
and discussed. The problems associated with the smaller ogives on Svínafellsjökull and the ridges below the ice falls are considered.

Zusammenfassung. Beobachtungen und Messungen der Ogiven auf Morsárjökull, Svínafellsjökull und Falljökull sind angegeben und besprochen. Die mit den kleineren Ogiven auf Svínafellsjökull verknüpften Probleme und die Grate unter den Gletscherbrüchen werden erwogen.
\end{abstract}

FURTHER observations were made of the ogives on Morsárjökull6 and those on Svinafellsjökull were also examined during 1954 . Skaftafellsjökull does not appear to have any ogives, probably because its gradient is not nearly so steep as that of the other two glaciers. Reference to the ogives of Falljökull will be made briefly. These glaciers are shown in Fig. I (Part I, p. 564). 
GLACIOLOGICAL OBSERVATIONS ON SOUTH-WEST VATNAJÖKULL, ICELAND 647

Although ogives form under both the connected ice fall and the avalanche fans of Morsárjökull on the north-west and south-east branches respectively, they are not equally distinct on the glacier surface. The ogives are very much more distinct below the avalanche fans, so that observations on this side of the glacier were more extensive than those on the other side. In I953 a cairn was left on the glacier between the 7 th and 8th ogives from the head of the glacier; this cairn was located in I954 and the number of ogives above it was 8, so that it was now between the 8th and 9th ogives. This is good evidence that one ogive forms each year. The distance apart of the first 8 ogives was measured by tape and the dip at their apices was measured by clinometer. The following results were obtained :

\begin{tabular}{|c|c|c|c|c|c|c|}
\hline \multicolumn{2}{|c|}{ Uppermost ogive } & \multicolumn{2}{|c|}{ Up-glacier dip } & 17 & degrees & \\
\hline 2nd distance & $91 \mathrm{~m}$. & ", & " & $3^{1}$ & ", & \\
\hline $3^{\text {rd }}$ & $136 \mathrm{~m}$ & , & , & 40 & , & \\
\hline $4^{\text {th }}$ & $142 \mathrm{~m}$ & , & ", & 57 & , & \\
\hline $5^{\text {th }}$ & $139 \mathrm{~m}$. & ", & ", & - & & \\
\hline 6th & $123 \mathrm{~m}$. & , & ," & 70 & ", & \\
\hline $7^{\text {th }}$ & $127 \mathrm{~m}$ & , & , & 84 & ", & \\
\hline 8th & $134 \mathrm{~m}$ & , & $"$ & $50-60$ & , & (variable) \\
\hline ," & $151 \mathrm{~m}$. & ", & ", & - & & \\
\hline
\end{tabular}

The distance apart of the ogives is on the average a little greater than the annual movement, which is about $108.5 \mathrm{~m}$. This may represent the amount by which the glacier has slowed down in the last few years as it has become increasingly thin?. If the dip of the ogive becomes less at depth, ablation will also have the affect of increasing the apparent distance apart of the ogives further down-glacier. The figures also show that the up-glacier dip of the ogives increases down-glacier. The dark bands of the ogives are mostly less than $3 \mathrm{~m}$. in width. Their dip was measured on the edges of crevasses, where they can be seen to dip down into the glacier (see Figs. 8 and 9, p. 65I).

The character of the avalanche fans was examined near their base where the upper ogives form. Towards the base of the avalanche fans the dip of the incipient ogives becomes irregular. Further up, in the lower part of the avalanche material, the new avalanche debris overlies the older material with a gentle down-glacier dip of about 20 degrees. The older summer avalanche material was very dirty; it incorporated much fine debris as well as larger, rounded stones up to about $15 \mathrm{~cm}$. in diameter. Near the edge of the glacier, at the lower end of the avalanche fans, large U-shaped crevasses, separated by smooth ridges, had formed (see Fig. 9).

On the north-west part of the glacier the ogives could not be located and measured. Close under the connected ice fall there are marked ridges of ice, these are fairly level but have a steep slope down-glacier. The ice appears to be coarsely crystalline with thin blue layers about $0.5 \mathrm{~cm}$. thick. These layers appear to be those called "tectonic blue bands" according to the terminology suggested in the fournal of Glaciology ${ }^{8}$. These bands give a layering to the ice which is nearly vertical throughout the upper part of the glacier, dipping 80-90 degrees up-glacier. The strike of the blue layers runs parallel to the foot of the ice-fall.

The ogives on Svinafellsjökull show several features of interest. The distance apart of the dark bands were measured by tape near the site of the flow observations (see Fig. 4, p. 649). The bands could be distinguished fairly clearly from the top of the trim-line so that measurements were directed from there. The dark bands in this area averaged $35 \mathrm{~m}$. apart. These bands could be seen on a photograph (Fig. 10, p. 65I) taken a little further down-glacier and their distance apart could be compared with larger ogives also visible on the photograph but in an area too crevassed for direct measurement. The larger ogives were five times the distance apart of the smaller ones, that is, $175 \mathrm{~m}$. apart. It is significant that the annual movement of the glacier in the same vicinity is 172.5 $\mathrm{m}$. The larger ogives are therefore clearly annual in character, but the more conspicuous smaller ones are not. 
Svinafellsjökull is fed from the high volcanic dome of Öraefajökull via a steep ice fall about $500 \mathrm{~m}$. high. The area at the base of the ice fall was examined and a profile surveyed for a distance of $2300 \mathrm{~m}$. by altimeter; the profile is shown in Fig. 7 (p. 649). It shows a series of ridges below the ice fall; these were of smooth ice with large transverse crevasses (Fig. II, p. 65I). In the troughs dirty snow was found near the foot of the ice fall. The ice was similar to that under the ice fall of Morsárjökull, being coarsely crystalline with thin "tectonic blue bands". These bands were nearly vertical or had very steep up-glacier dips throughout the area examined from the flow stakes to the foot of the ice fall. The distance apart of the crests of the ridges under the ice fall do not correlate with either the distance apart of the smaller ogives or the larger annual ones. They are somewhat irregular in spacing and height but gradually die out down-glacier till the surface of the glacier is nearly flat and little crevassed.

Ogives were also found on Falljökull, a very steep glacier draining from Öraefajökull (shown in Fig. I, Part I, p. 564). Their spacing was clearly much too close for them to correlate with the annual movement of the glacier so that they are probably similar in origin to the closer ogives on Svinafellsjökull. The distance apart of the ogives was measured by pacing, giving the approximate distance between successive ogives in metres as follows: $22,40,27,18,55,21,48,35$. The bands were distorted, faulted and fractured and sometimes bifurcated.

One of the problems raised by these observations is to account for the occurrence of nonannual as well as annual ogives in the same glacier at the same time.

A theory to explain the formation of ogives must take into account at least four different features; the annual ogive, the smaller feature of a similar type, the tectonic blue bands which are found throughout the glacier and the ridges which only occur beneath the ice falls where the gradient flattens.

The crevasse pattern suggests possibilities concerning the type of ice-flow according to the work of $\mathrm{Nye}^{9}$. Under the ice falls and for some distance down-glacier the crevasse pattern suggests a zone of compressive flow, which may be associated with thrust planes within the ice. This type of crevasse pattern is found on Morsárjökull, Falljökull and Svínafellsjökull. Lower down on Svinafellsjökull the crevasse pattern suggests extending flow while between the two zones the ice is very flat with few crevasses. This should indicate that the bed of the glacier is longitudinally concave below the ice fall but, on Svínafellsjökull at least, becomes convex lower down. There is also a small area of extending flow suggested on the north-west side of Morsárjökull a short distance below the connected ice fall ; this may point to the lip of a rock-basin further up-glacier, beneath the ice fall.

The significance of the crevasse pattern and associated type of glacier flow, with regard to the development of ogives, lies in the possibility of thrust zones, along which material can move up from the base of the glacier, below the ice falls and avalanche fans. This would account for the three-dimensional nature of the ogives.

Little dirt appears to reach the surface of Svinafellsjökull along such possible zones of thrusting except perhaps at the edge of the glacier (Fig, ro), where the ogives are more conspicuous. The upper dark bands of the ogives on the south-east part of Morsárjökull show a considerable concentration of fine dirt and numerous larger rounded stones are also present (Fig. 8). Dirt and boulders beneath the connected ice fall of Morsárjökull may reach the glacier surface from the bed because pink agglomerate blocks are found which do not appear to have come from the exposed valley walls. These blocks are numerous and large on one part of the glacier.

One of the main problems arising from the observations on Svinafellsjökull is to establish the connexion between the ridges beneath the ice fall and the ogives. The distance apart of the ridges is not very even and does not correlate with the distance apart of the annual ogives $(175 \mathrm{~m}$.) or the smaller ogives $(35 \mathrm{~m}$.) as shown on Fig. 7 . The ridges are $82 \mathrm{~m}$. apart on the average where they are best developed. There is a tendency for every fifth ridge to be larger than the intermediate ones where these are largest. If the ridges and ogives are connected, the smaller distance between ogives could be accounted for by the slowing up of the glacier flow where the surface slope 
GLACIOLOGICAL OBSERVATIONS ON SOUTH-WEST VATNAJÖKULL, ICELAND 649 of the ice becomes much less steep below the ice fall; here the ridges die out and the ogives start.

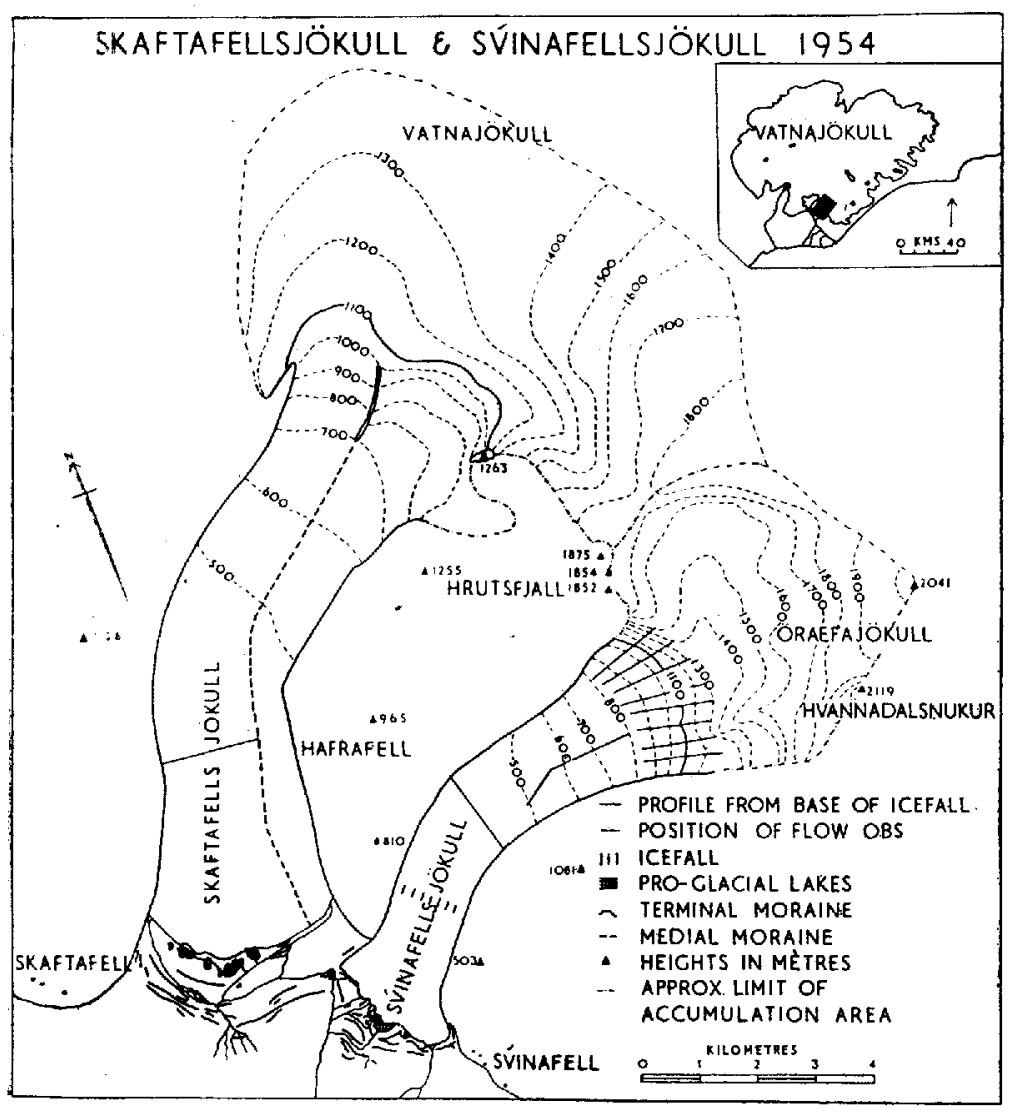

Fig. 4. (repeated from Part I)

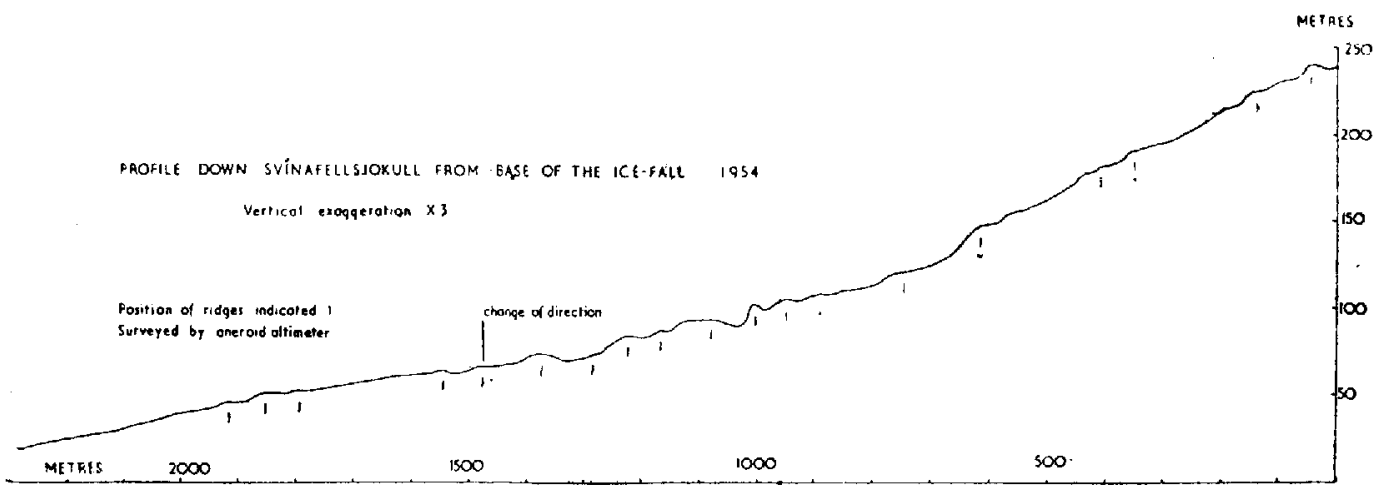

Fig. 7

The flow of the glacier is in some way responsible for the formation of the ridges and the ogives, and the fact that both occur beneath connected ice falls suggests that the features are 
related. It is known that glacier flow is not continuous and steady from the work of many glaciologists of which the Battle ${ }^{10}$ and Haefeli ${ }^{11}$ may be cited as examples, and from the observations made on the flow of Morsárjökull in 1953 and 1954 (see ref. 2, Part I, p. 569). This irregularity of flow is probably related to variations in the supply of ice, via the ice fall or avalanche fans in this instance.

The irregularity of flow may be of different orders; on a small scale the glacier may move in jerks rather than continuously, while on a larger scale periodic or seasonal surges of flow may occur when the increased pressure resulting from greater supply overcomes the strength of the ice. Orowan 12 has calculated that the increase of rate of flow changes very rapidly with change of stress. He considers that the glacier flow increases by about too per cent for an increase of weight of I per cent by the winter snowfall.

Short period movement may result in the formation of the "tectonic blue bands" already mentioned, by differential movement of thin layers of ice as described by Demorest ${ }^{13}$. The smaller ogives may represent an intermediate type of movement, the size and spacing of the band depending on the character of the glacier. The movement of ice down the ice fall may lead to a thickening of the glacier at the base which will continue until the stress is greater than the strength of the ice. This would allow rapid movement and the formation of a ridge at the base of the ice fall; the pressure would be released and the flow would again fall off.

The conditions of Svinafellsjökull seem to be such that five ridges form each year which may be converted into true ogives down glacier. The annual ogive may be formed in a similar way, but seasonal factors are significant in its genesis. The winter snowfall reaches a maximum in February and March, while the glacier is coldest and driest about the same period and therefore probably strongest. This allows a considerable build-up of pressure in the ice fall. With the increasing warmth and water in the glacier this may lead to a correspondingly great surge, resulting in the formation of a larger ridge. This may subsequently become an annual ogive, lower down the glacier, as ablation reveals lower layers and differential movement in cross-section accentuates the ogive form.

The ice fall of Falljökull appears to be more unstable and less regular in its movement than that of Svinafellsjökull, so that the formation of ogives is less regular and those that do form are cut by faulting and shearing near the snout of the glacier.

The formation of ogives has been shown to be an annual occurrence on both Morsárjökull and Svínafellsjökull, but similar features are formed on the latter glacier and on Falljökull at a shorter time interval also. Many problems remain to be solved concerning these interesting features.

MS. received 5 February 1955

\section{RE F E R E N C E S}

6. Ives, J. D., and King, C. A. M. Glaciological observations on Morsárjökull, S.W. Vatnajökull, Part I. Journal of Glaciology, Vol. 2 , No. 16, 1954, P. 423-28.

7. Ahlmann, H. W. The Styggedal glacier in Jotunheim, Norway. Geografiska Annaler, Arg. 22, Ht. 3-4, 1940, p. 95I30 (p. 127).

8. Glacier bands, Conference on terminology, Fournal of Glaciology, Vol. 2, No. 13, I953, p. $229-32$.

9. Nye, J. F. The mechanics of glacier fow. fournal of Glaciology, Vol. 2, No. 1 2, 1952, p. $82-93$.

ro. Battle, W. R. B. Glacier movement in north-east Greenland, I949. Fournal of Glaciology, Vol. I, No. 10, r95 I, p. $559-63$.

1. Haefeli, R. Some observations on glacier flow. fournal of Glaciology, Vol. r, No. 9, 1951, p. 496-500.

1 2. Joint meeting of the British Glaciological Society, the British Rheologists' Club and the Institute of Metals. Fournal of Glaciology, Vol. 1, No. 5, 1949, p. 231-36.

13. Demorest, M. Ice sheets. Bulletin of the Geological Society of America, Vol. 54, 1943, p. 363-400. 

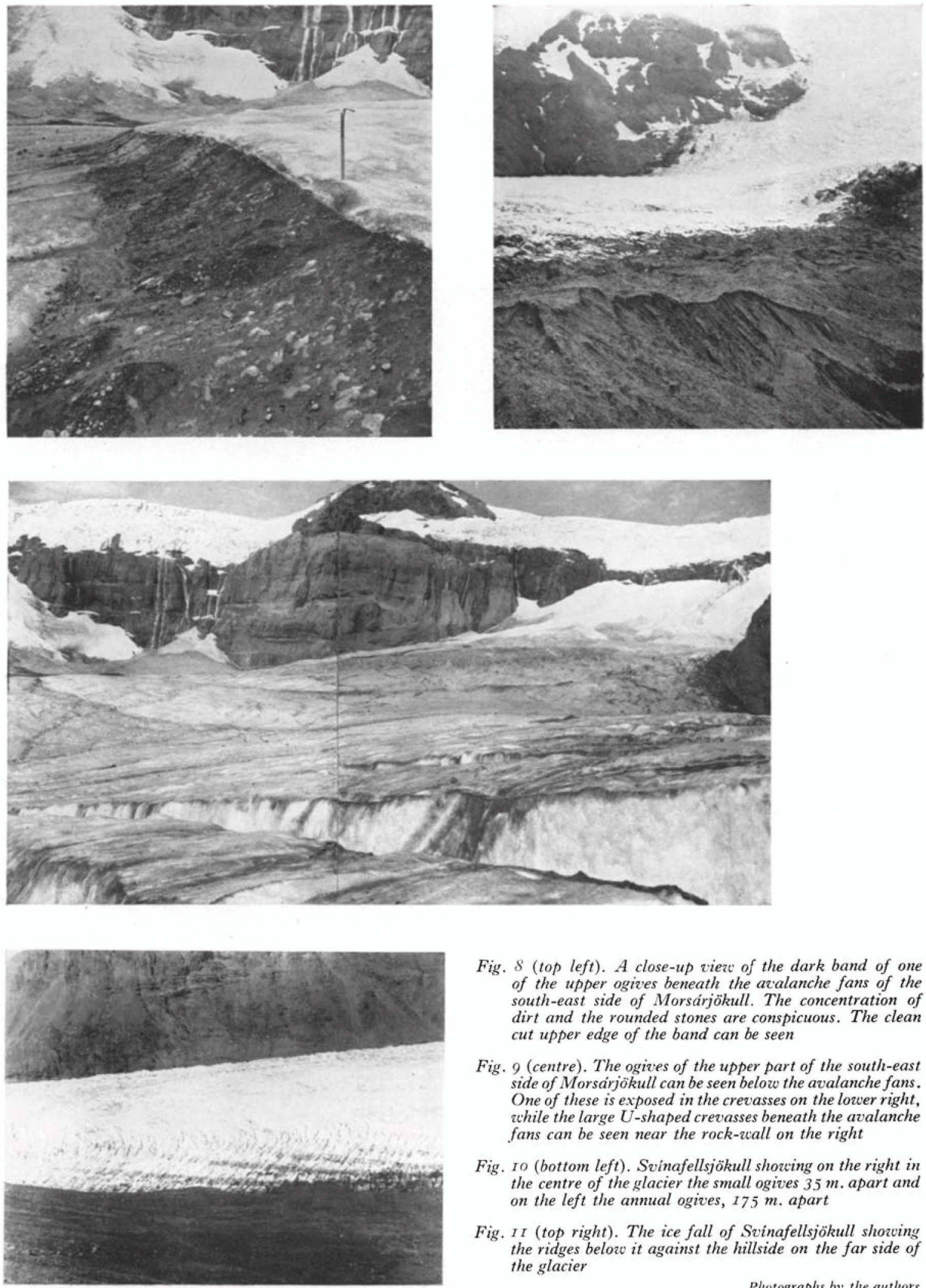

Fig. 8 (top left). A close-up view of the dark band of one of the upper ogives beneath the avalanche fans of the south-east side of Morsárjökull. The concentration of dirt and the rounded stones are conspicuous. The clean cut upper edge of the band can be seen

Fig. 9 (centre). The ogives of the upper part of the south-east side of Morsariökull can be seen below the avalanche fans. One of these is exposed in the crevasses on the lower right, while the large $U$-shaped crevasses beneath the avalanche fans can be seen near the rock-wall on the right

Fig. Io (bottom left). Svinafellsjökull shouzing on the right in the centre of the glacier the small ogives $35 \mathrm{~m}$. apart and on the left the annual ogives, $175 \mathrm{~m}$. apart

Fig. II (top right). The ice fall of Svinafellsjökull showing the ridges below it against the hillside on the far side of the glacier 

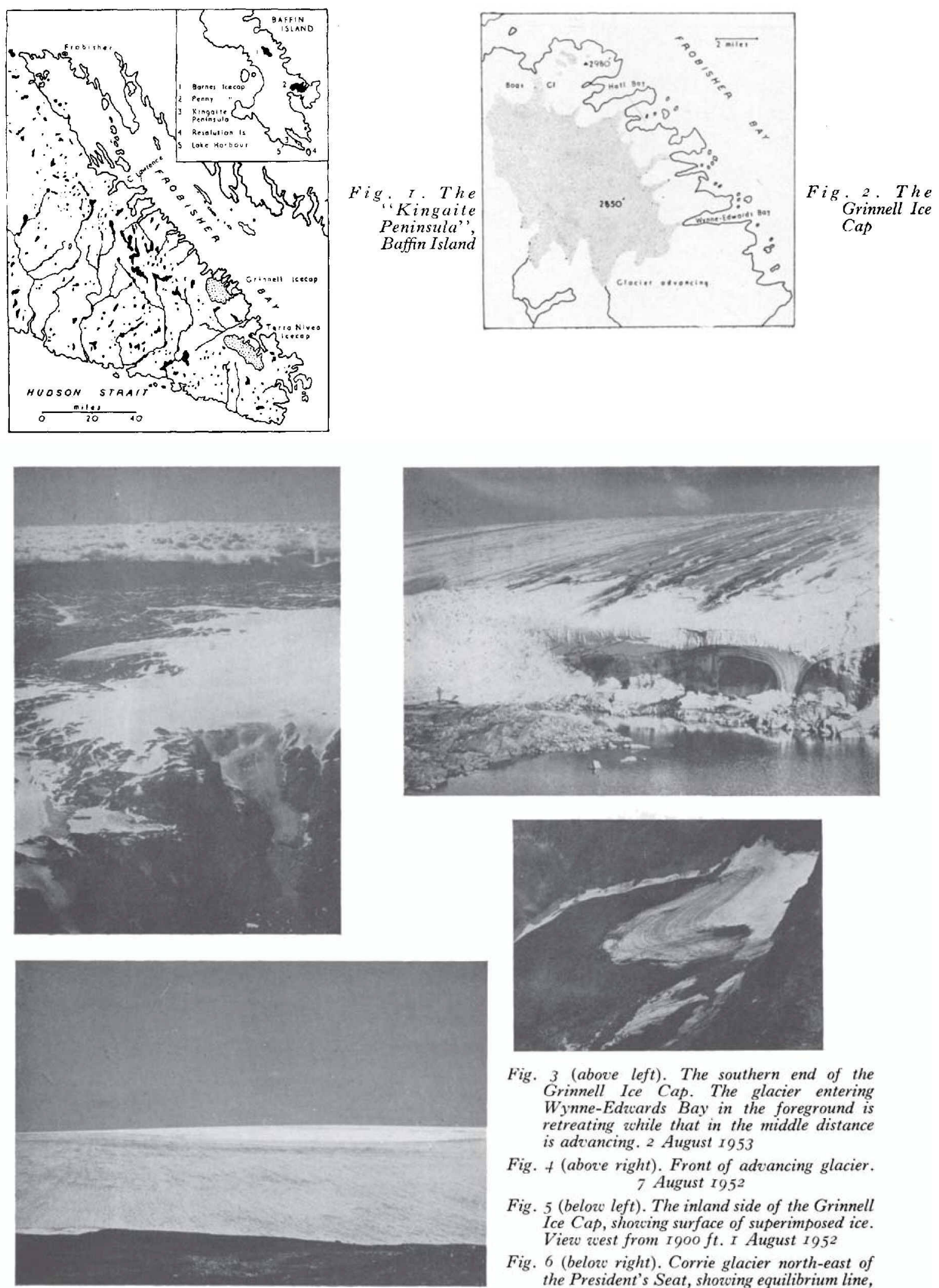

Fig. 3 (above left). The southern end of the Grinnell Ice Cap. The glacier entering Wynne-Edwards Bay in the foreground is retreating while that in the middle distance is advancing. 2 August 1953

Fig. + (aboze right). Front of advancing glacier. 7 August $195^{2}$

Fig. 5 (below left). The inland side of the Grinnell Ice Cap, showing surface of superimposed ice. View west from I $900 \mathrm{ft}$. I August $195^{2}$

Fig. 6 (below right). Corrie glacier north-east of the President's Seat, showing equilibrium line, developed firn line, and tico temporary firn lines. 21 August 19.52 